\title{
EFFECTS OF SOCIAL MEDIA ON CONSUMER BRAND AWARENESS AND PATRONAGE OF NIKE LAKE RESORT SERVICES IN ENUGU: AN INNOVATION ADOPTION THEORY \& HIERARCHY OF EFFECTS MODEL EXPOSITION
}

\author{
Ikpo Kobi P., Okolo Victor O. and Oranusi Ifeanyichukwu N.
}

\author{
${ }^{1}$ Department of Marketing, University of Nigeria Nsukka, Enugu Campus, Nigeria. \\ ${ }^{2}$ Department of Marketing, University of Nigeria Nsukka, Enugu Campus. \\ Email: victor.okolo@unn.edu.ng; \\ ${ }^{3}$ Department of Marketing, Nnamdi Azikiwe University, Awka, Nigeria.
}

Cite this article:

Ikpo K.P., Okolo V.O., Oranusi I.N. (2021), Effects of Social Media on Consumer Brand Awareness and Patronage of Nike Lake Resort Services in Enugu: An Innovation Adoption Theory \& Hierarchy of Effects Model Exposition. British Journal of Management and Marketing Studies 4(2), 71-88. DOI: 10.52589/BJMMSPYHGHIPD.

\section{Manuscript History}

Received: 8 May 2021

Accepted: 6 June 2021

Published: 20 June 2021

Copyright $\odot 2020$ The Author(s). This is an Open Access article distributed under the terms of Creative Commons AttributionNonCommercial-NoDerivatives 4.0 International (CC BY-NC-ND 4.0), which permits anyone to share, use, reproduce and redistribute in any medium, provided the original author and source are credited.
ABSTRACT: Communication has initiated a paradigm shift from the traditional to new the new social media. This study investigated the influence of Twitter messages and Facebook messages on consumer brand awareness and patronage of Nike Lake Resort services in Enugu: an innovation adoption theory \& hierarchy of effects model exposition. The specific objectives of the study were to ascertain the extent of the influence of Twitter messages on consumer brand awareness and patronage of Nike Lake Resort services. Also, to determine the extent of the influence of Facebook messages on consumer brand awareness and patronage of Nike Lake Resort services. This study contributed to the extant gap in marketing literature by using Twitter messages and Facebook messages to promote Nike Lake Resort services in Enugu. The population of the study includes guests of Nike Lake Resort selected through a convenient sampling technique. The survey method was adopted and the sample size of 384 was determined using Freud and William's formula known as the Z-score method. Cronbach's alpha was used to determine the reliability of the instrument of 0.870. The Pearson product-moment correlation coefficient was used to analyse data. Findings revealed a significant positive influence of Twitter messages on consumer brand awareness and patronage of Nike Lake Resort services $(r=$ 0.937, $p<0.05$ ). Also, it was revealed that there is a significant positive influence of Facebook messages on consumer brand awareness and patronage of Nike Lake Resort services ( $r=0.943$, $p<0.05$ ). Twitter messages and Facebook messages are effective marketing tools for communicating Nike Lake Resort services to consumers. There is need for Nike Lake Resort to continuously improve on the use of Twitter messages and Facebook messages channels to help boost consumer awareness and patronage in future.

Keywords: Twitter Messages, Facebook Messages, Consumer Brand Awareness, Consumer Patronage, Innovation Adoption Theory, hierarchy of Effects Model. 


\section{INTRODUCTION}

Victorious and award-winning companies that always strive to earn competitive advantage would proactively display their prowess and capabilities by grasping and manipulating every opportunity that guarantees success (Tapera, 2014). Indeed, companies strive not to be vanquished nowadays; rather, they prefer to be in the forefront of every program targeted towards satisfying customer requirements (Appel et al., 2020; Woodcock \& Stone, 2012). These companies unequivocally despise the culture of window dressing as they deliberately project themselves as a genuine, credible and socially responsible entity in all dimensions of their business operations in order to establish a win-win situation with their customers. However, social media is a sequence of both hardware and software technological innovations which allow the creation of inexpensive content vis-a-vis sharing, interacting and communicating products, sales and other social messages by online users (Abzari et al., 2014), and it is a popular trend today, especially among young people. Gangadharbatla (2008) supports this view by saying that the popularity of social media is most clearly observed among young adults as most young adults have a social media account, which they visit regularly. Social media has many benefits which according to Mobango and Wagandu (2017) include brand awareness creation, cost efficiency, target audience orientation, customer insights improvement, connectivity, better customer services and improved patronage. These traits of social media make it the fastest-growing channel for marketing communication across the globe (Pentina et al., 2013).

Sequel to that, there is an outright paradigm shift as most corporate entities are diverting to the use of social media much more than the traditional media (TV, radio, newspaper and magazine) to communicate with their customers (Alhadad, 2015; Otugo et al., 2015). In Kenya for instance, social media has tremendously provided an avenue for individuals and businesses to expand their communication horizon through freely and seamlessly sharing of contents (Mobango \& Wagandu, 2017). In other words, many businesses now seamlessly communicate with their potential and current customers as well as people from all walks of life can now equally communicate with one another on different issues on the public agenda. The social media channels include Facebook, Twitter, Flickr, Whatsapp, LinkedIn, Trip Advisor, YouTube, Instagram, Pinterest and Snapchat, Viber, Skype, Reddit, Picasa, Google Plus, and WhatsApp (Okolo et al., 2017; Altinay et al., 2017; Groza \& Domagalski, 2017).

While the adoption of social media is mainstream vis-à-vis sharing of contents by users through regular interaction via community building, Twitter messages are in the vanguard of this evolutionary innovation and offer its users real-time and topical news update on issues in the public agenda (Zubiaga et al., 2013). Facebook is equally quintessential and fluoresces every time a user connects to it to exchange information and knowledge on past, present and future events. For young adults, where a sense of belonging and demonstration of knowledge are considered important, social media also allow them to express their association, identity, build their social networks and convey their views to their peers (O'Reilly et al., 2012). Many studies had been conducted on the relevance of social media (Okonkwo et al., 2015; Dhanushanthini, 2017; Murillo et al., 2016; Ishola et al., 2017). Ergo, this study seeks to investigate social media impact on consumer brand awareness and patronage of products and services of Nike Lake Resort. While most studies had been done on physical products instead of intangible products, this particular one sought to fill a gap in the literature by delving into the influence of social media on consumer brand awareness and patronage of services providing companies in Enugu. 
Furthermore, most companies, particularly those in the hospitality industry in Nigeria portray a lukewarm attitude and appear not to have fully adopted Twitter and Facebook Innovative technology to connect with their customers in marketing their service (Ekwueme \& Okoro, 2018; Okonkwo et al., 2015). These firms seem ignorant of the importance of social media in the hospitality industry in the area of creating awareness, developing business strategy, business growth and development; and this situation may have led to many of them recording poor publicity, minimal awareness level, low patronage, few loyal participants, weak financial base, customer dissatisfactions and poor market share (Nyekwere, 2012). It is therefore, in the light of the foregoing that the researchers seek to ascertain the extent of the relationship between Twitter messages and consumer brand awareness and patronage of Nike Lake Resort services and also, to determine the extent of the relationship between Facebook and consumer brand awareness and patronage of Nike Lake Resort services, to recommend strategies in line with international and global best practice to enable adequate brand awareness and ultimately ensure patronage of Nike Lake Resort in Enugu.

\section{REVIEW OF RELATED LITERATURE}

\section{Overview of the Social Media}

The internet has revolutionized the manner and schedule of marketing programs (Atefeh \& Khreich, 2013). In other words, business etiquette has made a U-turn (Leefla et al., 2014). This technology is the forerunner of the new media popularly known as social media. Emphatically, the internet is the sole carrier of social media contents. It has unquestionably led to tremendous customer insights, multifarious customer relationships, and innumerable business and customer exchanges in form of products, services, ideas, events and other social and environmental issues (Leeflag et al., 2014). It transmits referrals to customers through virtual word-of-mouth. Research findings have revealed that social media impacts online word-of-mouth regarding consumer products and services (Liu \& Lopez, 2016). It can be defined as the virtual resources through which people share contents such as texts, photos, and videos which are ideas, insights, opinions, and relationships.

\section{Social Media Advertising}

Social media advertising has the greatest velocity in message transmission about brand awareness creation and establishment than the traditional TV, radio, newspaper and magazine advertising (Sadhasivam \& Priya, 2015). Advertising is defined as a paid one-way asymmetrical means of relaying messages to a mass audience through the mass media (Can \& Kaya, 2016). It is a paid non-personal communication by an identified sponsor (Kotler \& Keller, 2006; Kotler \& Armstrong, 2012; Belch \& Belch, 2003). It is the principal component of integrated marketing communications that bring information about a product, service or brand to the target and/or mass media audience (Can \& Kaya, 2016). Its cardinal objective is to disseminate information to the masses through premeditated persuasion (Nwosu \& Nkamnebe, 2006).

However, social media has unequivocally soared to indomitable heights vis-a-vis communication than any other media in the 21st century (Ohajionu \& Mathews, 2015). Social media advertising is simply conducting advertisements through social media networks. In other words, it's placing and airing advertising online. The publisher who integrates 
advertisements into its online material and the advertiser are committed and in charge of bringing the ad messages to life (Anusha, 2016). Social media advertising is very germane in the operations of many businesses in our contemporary world today (Can \& Kaya, 2016). To them, consumer attitude and inclination toward social media advertising is receiving colossal attention. Social media advertising has evolved and has been ubiquitously adopted by many organizations (Anusha, 2016). It is a very effective and efficient advertising medium. Its growth is the fastest in digital advertising parlance (Aslay et al., n.d).

Many companies have launched official Facebook pages, Twitter messages accounts, and corporate blogs to interact and transact businesses with their clientele (Ohajionu \& Mathews, 2015). Direct feedback from consumers is elicited from the internet which can target individual messages (Haida \& Rahim, 2015). In a study conducted in Mexico by (Murillo et al., 2016), it was revealed that other advertising forms were not acceptable to millennials like the Twitter messages advertising.

\section{Hypotheses Development}

\section{Twitter Message Medium}

As an online social media channel, Twitter messages allow users to communicate messages via tweets (Wikipedia, 2018). It was founded by Jack Dorsey, Evan Williams, Biz Stone and Noah Glass in March 2006 and was formally launched in July the same year (Alsanie, 2015). The headquarters of Twitter messages is in San Francisco, USA. The number of characters required for tweets before was 140, but it has been doubled in 2017 said Wikipedia (2018; Kwak et al., 2010). Underpinning this view, Alhabash and Ma (2017) noted that Twitter messaging was founded in October 2006 (Java et al., n.d; Williams et al., 2013) as a microblogging site allowing users to tweet 140 characters to their audience. It gives users the chance to post and read tweets that are short messages.

Tweets can only be posted by those who are formally registered with them but the unregistered users can only read them, said Wikipedia (2018). In 2007, within eight months of its launch, Twitter messages recorded 94 million users (Java et al., n.d). This is in contrast with Kwak et al. (2010) who argued that in 2009 about 41 million people started tweeting. Presently, about 320 million people are active users of Twitter messages while about 1 billion monthly visits were recorded about a year ago (Alhabash \& Ma, 2017). Twitter messages improve word-of-mouth marketing and expedite viral messages. Twitter messages can be used to enhance communication building and critical thinking (Okolo et al., 2017). It was used in a graduate seminar requiring students to post tweets to extend and make classroom discussions more fun (Domizi, 2013). Tweets report a variety of news stories ranging from local, regional, international and global news bothering on manufacturing, terrorism, politics, economy, religion, education, science, environment, fashion, entertainment, sports, wildlife etc. (Zubiaga et al., 2013; Atafeh \& Khreich, 2013). Nevertheless, the assumed declining rate in Twitter messages usage, Fiegerman (2016) and Alhabash and Ma (2017) contrarily illustrated that no significant decline had been observed. According to Alhabash and Ma (2017), one-third of online young adults between the ages of 18 and 29 years were reported using Twitter messages in 2013, compared to 37\% who used it in 2014 and 32\% in 2015. 
In addition, Twitter messages have made throughput for research and development available since its origin in 2006. And this has yielded a databank or repository of published papers that many scholars could easily lay their hands on whenever they need them for the furtherance of research (Williams et al., 2013). It has been revealed that Twitter messages have the capacity to communicate a company's products and services and elicit purchase actions for them. Tentatively this study proposes that:

H1: There is a significant influence of Twitter messages on consumer brand awareness and patronage of Nike Lake Resort services.

\section{Facebook Message Medium}

The birth of Facebook is in Menlo Park in California, USA. It is an online social media services company that Mark Zuckerberg and his colleagues and roommates such as Eduardo Saverin, Dustin Moskovitz, Andrew McCollum and Chris Hughes in 2004 launched its website (Wikipedia, 2018). It is the most popular social media (Akpan et al., 2015; Anh \& Tuan, 2016; Altinay et al 2017). Leaning on these statements, Caers et al. (2013) remarked that a decade ago, Facebook has been one of the most significant social media revolutions. However, Facebook is defined as a famous free social networking website that grants the opportunity to its registered user to establish, nurture and sustain mutual relationships with family members, community leaders, governments, friends, and colleagues through the exchange of messages via profile creation and uploading of videos and pictures (Rouse \& Dean, 2014). Facebook has "one billion monthly active users at the end of 2012." A large number of these users live outside the US and services are available in many different languages, making Facebook a global platform (Caers et al., 2013).

Ho (2013) in a study titled "consumer behaviour on Facebook: does consumer participation bring positive consumer evaluation of the brand?" revealed that Facebook has direct positive and significant effects on brand trust and community identification. In another study, it was discovered that Facebook was able to influence the intent of the students vis-a-vis the promotion of foreign degree programmes in Malaysia (Ishola et al., 2017). Relatedly, the purchase intentions of consumers were revealed to be influenced by Facebook (Yildiz et al., 2016). It was also revealed in another study that young consumers had been influenced heavily through Facebook advertising and the Facebook environment (Rehman et al., 2014).

Tentatively, this study proposes that:

$\mathrm{H} 2$ : There is a significant influence of Facebook messages on consumer brand awareness and patronage of Nike Lake Resort services.

\section{Consumer Brand Awareness}

Brand awareness is simply making a brand known (Ahmad et al., 2014). It is the perception of a brand in the mind of a consumer. In their study, it was revealed that brand awareness has a positive relationship with brand loyalty and brand credibility. In another study, it was discovered that brand equity is influenced by brand awareness and brand loyalty (Asif et al., 2015). Brand awareness has a remarkable effect on consumer purchase decisions (Macdonald $\&$ Sharp, 2000). It guides a consumer in choosing among different and competing brands in the shopping mall. 
The first assignment of marketing communications is creating, nurturing and sustaining brand awareness (Cizmeci \& Ercan, 2015). It is very important in many corporate branding strategies (Homburg et al., 2010). However, Bertsch and Ostermann (2011) described two levels of brand awareness. They include the inability of the consumer to recognize something already perceived in a brand the first time the brand elements are presented to him or her and the ability of the consumer to recognize a brand without being presented any of the brand features. He called the former passive brand awareness and the latter active brand awareness. Brand recognition, brand recall, brand top of mind and brand name dominance are the four levels of the brand awareness pyramid (Cizmeci \& Ercan (2015).

\section{Effects of Social Media on Consumer Brand Awareness and Patronage}

Advertising on Facebook and Twitter messages influence consumer patronage (Okolo et al., 2018; Akpan et al., 2015). This view was supported by Nyekwere et al. (2013) who observed that goods and services advertised on social media attract huge consumer patronage. Research conducted by Chukwu and Ifediora (2014) revealed that social media (Facebook and Twitter messages) influenced consumer patronage of online shops significantly. Social media can change consumer behaviour and further mount pressure on the consumer to scut from the affective state to cognitive state (Ioanas \& Stoica, 2014). Apparently, from the perspective of politics, a study was conducted by Ogbuji and Ogbubula (2018) and it was also discovered that social media was instrumental to voters' intention to cast their ballots for their chosen political candidates.

Moreover, in another study in the travel and tourism industry in Sri Lanka, Dhanushanthini (2017) revealed that social media marketing has a positive and significant effect $(73.4 \%)$ on brand equity. Alhaddad (2015) revealed also that social media advertising has an impact on brand awareness. In line with this, Bayne and Cianfrone (2013) and Bilgin (2018) supported that brand awareness is tremendously influenced by the use of social media. Similarly, in a related study, Alam and Khan (2015) also discovered that social media have a significant impact on brand awareness. Ali et al. (2016) also discovered that social media marketing affects consumer perception and purchase decisions. In another related study by Abzari et al. (2014), it was revealed that social media influenced consumer brand attitude and intention to buy from Khodro Company in Iran.

\section{The Innovation Adoption Theory (IAT)}

The innovation adoption theory (IAT) which is also known as the diffusion of innovation theory (DIT) introduced by Everett Rogers in 1962 highlighted the stages a target consumer undergoes before making an initial purchase decision (Rogers, 2003). F York (2009), innovation adoption theory postulates several stages through which a target customer passes from a state of unawareness, awareness, interest, trial to purchase/adoption. Kotler, Armstrong and Opresnik (2018) defined the adoption process as the mental stages through which a consumer-first gains information about an innovation and forges ahead to adopt it.

Okolo et al. (2017), and Kotler, Armstrong and Opresnik (2018) described the differences in consumer or individual innovativeness in figure 1 below: the innovators are the first group who choose to adopt an innovation or product as soon as they see it. They are extroverts, aggressive, venturesome and expeditious. The early adopters are diligently careful and are guided by respect. They are naturally the leader of their peerage or opinion leaders whom their constituency look up to to make critical purchase decisions. Then the early majority is 
independent consumers who, although conscious of taking purchase risks, forbid being the last to adopt innovation; even though they are not opinion leaders on their own. The late majority is sceptical and risk-averse consumers who choose to adopt a product or service when they are sure that the adoption of the innovation wouldn't hurt. Finally, innovation is adopted lastly by the laggards. They are conservatives, tradition-bound and afraid of change; and would not key into an innovation until everyone has adopted it.

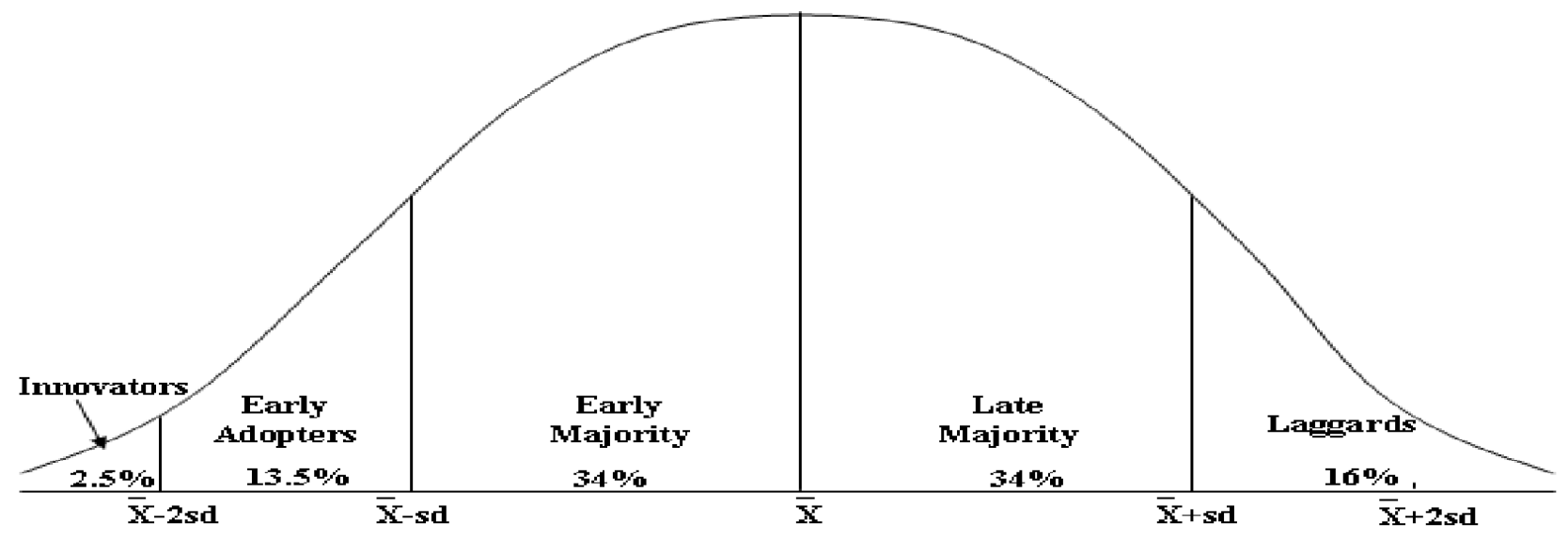

Fig. 1: Innovation Adoption Theory.

Source: Sahin, I. (2006).

\section{Hierarchy of Effects Model}

The hierarchy of advertising effects models was developed by Robert Lavidge and Gary Steiner in 1961 (Sadeghi et al., 2013). It had been applied by many professionals in assessing advertising objectives many decades ago (Sadeghi et al., 2013). It represents the hierarchy in motion through which a consumer makes a purchase decision as a decision to buy a product may not be directly related to the advertisement a consumer hears or sees.

The hierarchy of effects model is based on classical psychology and separates consumer perception of advertising communication into cognitive, affective and motivational states (Ekberg, 2010). Instead of the routine six stages, Ekberg (2010) posited seven stages unaware, aware, knowledge, liking, preference, conviction, and purchase. Ekberg also described other constructs in the hierarchy of effects model in figure 2. According to Ekberg, the cognitive state is where individual thought is domiciled and at this stage, the ad makes information and facts available. Under the cognitive state, the consumer is either unaware, aware or knows a product through ad messages. The affective state has domiciled the realm of emotion and the objective of the ad is to secure consumer perception and feeling. Under an effective state, the consumer develops liking and preference for the product. While in the conative state lies the realm of motive and the ad is intended to enkindle the desire of the consumer to buy the product. 


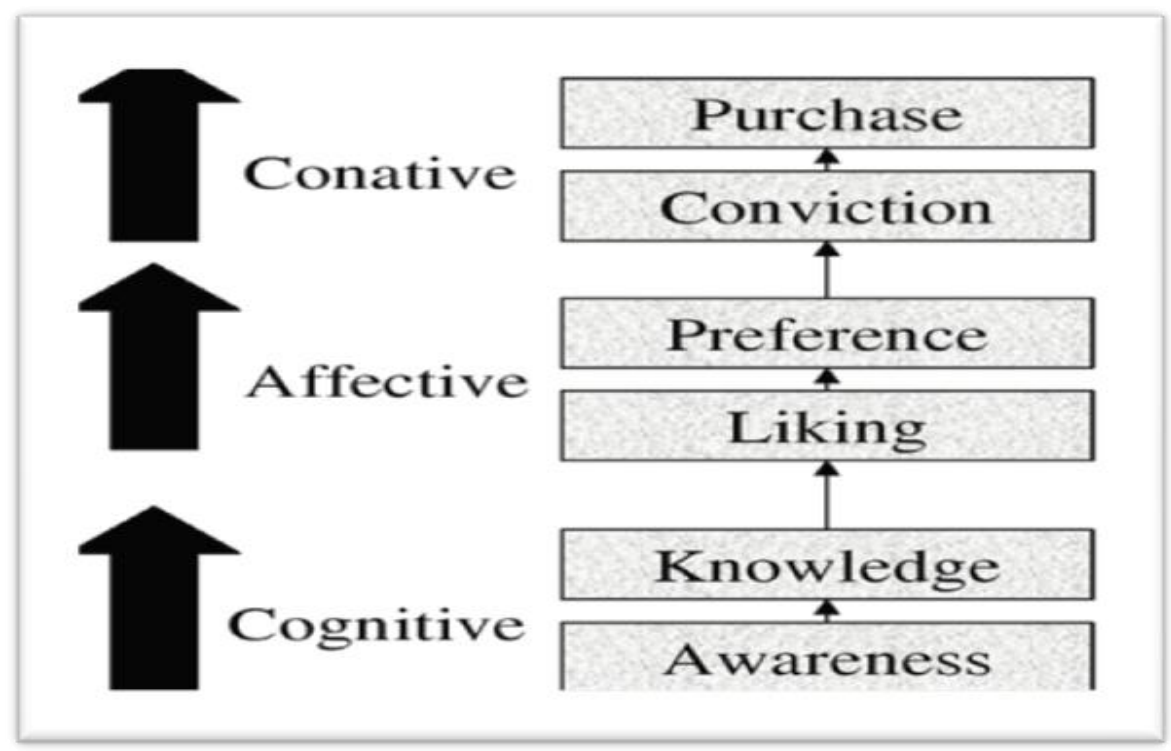

Figure 2: Hierarchy of Effects Model

Source: https://www.google.com/search?biw

\section{RESEARCH METHODS}

The researcher employed a survey method by administering structured questionnaires to gather primary data from customers who purchase the services of Nike Lake Resort in Enugu. The scope covered social media (Twitter messages and Facebook messages) capacity in creating brand awareness and patronage of Nike Lake Resort services: a hospitality firm in Enugu. The population includes guests of Nike Lake Resort selected using convenience sampling techniques. Face and content validity were used to determine the validity of the instrument by giving questionnaires to marketing experts who vetted it so that the instrument can measure what it constructs accurately. The reliability of the study is 0.870 determined using Cronbach's alpha. The sample size was 384 determined using Freund and William's method of determining an unknown population. Thus, from the 384, 295 were correctly filled and validated. Analysis of data was done using Pearson's product-moment correlation coefficient with the aid of statistical package for social sciences (SPSS) software version 22.

\section{DATA PRESENTATION AND ANALYSIS}

The data obtained from the field study were presented and analyzed with descriptive statistics to provide answers to the research questions while the corresponding hypotheses were tested with Pearson's correlation and linear regression at 0.05 alpha levels. 
Table 1. Coded responses on the influence of Twitter messages on consumer brand awareness and patronage of Nike Lake Resort services.

\begin{tabular}{|c|l|c|c|c|c|c|c|}
\hline $\begin{array}{c}\text { S/N } \\
\text { o }\end{array}$ & \multicolumn{1}{|c|}{$\begin{array}{c}\text { Questionnaire items } \\
1\end{array}$} & $\begin{array}{c}\text { Strongly } \\
\text { agree }\end{array}$ & Agree & Neutral & Disagree & $\begin{array}{c}\text { Strongly } \\
\text { disagree }\end{array}$ & $\begin{array}{c}\text { Total } \\
\text { (Freq) }\end{array}$ \\
\cline { 3 - 7 } & Freq & Freq & Freq & Freq & Freq & \\
\hline 2 & $\begin{array}{l}\text { You got information about } \\
\text { services rendered by Nike } \\
\text { Lake Resort via Twitter }\end{array}$ & 138 & 100 & 15 & 25 & 17 & 295 \\
\hline & $\begin{array}{l}\text { Using Twitter video you } \\
\text { made your choice of service } \\
\text { through their displayed } \\
\text { product lines }\end{array}$ & 151 & 94 & 20 & 17 & 13 & 295 \\
\hline 3 & $\begin{array}{l}\text { Twitter messages about Nike } \\
\text { Lake Resort targets specific } \\
\text { customer (personal } \\
\text { messages) }\end{array}$ & 140 & 121 & 13 & 10 & 11 & 295 \\
\hline 4 & $\begin{array}{l}\text { You gave the management of } \\
\text { Nike Lake Resort feedback } \\
\text { on how they can improve } \\
\text { their services using Twitter }\end{array}$ & 126 & 132 & 15 & 14 & 08 & 295 \\
\hline 5 & $\begin{array}{l}\text { You purchased Nike Lake } \\
\text { services through their suasive } \\
\text { Twitter messages }\end{array}$ & 110 & 154 & 21 & 07 & 03 & 295 \\
\hline 6 & $\begin{array}{l}\text { You complained about } \\
\text { services dissatisfaction via } \\
\text { Twitter }\end{array}$ & 154 & 112 & 09 & 10 & 10 & 295 \\
\hline TOTAL & 819 & 713 & 93 & 83 & 62 & 1770 \\
\hline
\end{tabular}

Source: fieldwork, 2020

In table 1, based on responses 819 indicated strongly agree, 713 indicated agree, 93 indicated neutrality, 83 indicated disagree, while 62 indicated strongly disagree. This implies that Twitter messages have a significant and positive relationship with consumer brand awareness and patronage of Nike Lake Resort services. 


\section{Hypothesis One}

H1: There is a significant relationship between Twitter messages and consumer brand awareness and patronage of Nike Lake Resort services.

Table 2. Descriptive Statistics

\begin{tabular}{|l|r|r|r|}
\hline & \multicolumn{1}{|c|}{ Mean } & \multicolumn{1}{c|}{$\begin{array}{c}\text { Std. } \\
\text { Deviation }\end{array}$} & \multicolumn{1}{c|}{ N } \\
\hline Brand & 4.2486 & 0.88560 & 885 \\
Awareness & 4.1740 & 1.07796 & 885 \\
Twitter & & \\
\hline
\end{tabular}

Table 3. Correlations

\begin{tabular}{|ll|r|r|}
\hline & \multicolumn{1}{|c|}{$\begin{array}{c}\text { Brand } \\
\text { Awareness }\end{array}$} & Twitter \\
\hline Brand & Pearson & 1 & $0.937^{* *}$ \\
Awareness & Correlation & & 0.000 \\
& Sig. (2-tailed) & 885 & 885 \\
& N & $0.937^{* *}$ & 1 \\
\hline Twitter & Pearson & 0.000 & \\
& Correlation & 885 & 885 \\
& Sig. (2-tailed) & N & \\
& N & & 1 \\
& & & \\
&
\end{tabular}

**. Correlation is significant at the 0.01 level (2-tailed).

Table 2 shows descriptive statistics of the relationship between Twitter messages and consumer brand awareness and patronage of Nike Lake Resort services. The mean value of Twitter messages is 4.1740; while the standard deviation is 1.07796. Also, the mean value of consumer brand awareness and patronage of Nike Lake Resort services is 4.2486; while the standard deviation is 0.88560 . By careful observation of standard deviation value, it can be said that there is about the same variability of data points amongst dependent and independent variables. This implies that Twitter messages have a significant and positive relationship with consumer brand awareness and patronage of Nike Lake Resort services.

Also, Table 3 shows the Pearson correlation coefficient for Twitter messages and consumer brand awareness and patronage of Nike Lake Resort services. The correlation shows 0.937. This value indicates that the correlation coefficient is significant at 0.05 level ( 2 tailed) and implies that there is a significant and positive relationship between Twitter messages and consumer brand awareness and patronage of Nike Lake Resort services $(r=0.937)$. The computed correlation coefficient is greater than the table value of $r=0.195$ with 228 degree of freedom ( df $n-2)$ at alpha level for a two-tailed test $(r=0.937, p<0.05)$. 
Table 4. Coded responses on the influence of Facebook messages on consumer brand awareness and patronage of Nike Lake Resort services.

\begin{tabular}{|c|l|c|c|c|c|c|c|}
\hline \multirow{2}{*}{$\begin{array}{c}\text { S/N } \\
\text { o }\end{array}$} & \multicolumn{1}{|c|}{ Questionnaire items } & $\begin{array}{c}\text { Strongly } \\
\text { agree }\end{array}$ & Agree & Neutral & Disagree & $\begin{array}{c}\text { Strongly } \\
\text { disagree }\end{array}$ & $\begin{array}{c}\text { Total } \\
\text { (Freq) }\end{array}$ \\
\cline { 3 - 7 } 1 & $\begin{array}{l}\text { Freq } \\
\text { You got information about } \\
\text { services rendered by Nike } \\
\text { Lake Resort via Facebook }\end{array}$ & 158 & 92 & Freq & Freq & Freq & \\
\hline 2 & $\begin{array}{l}\text { Using Facebook video you } \\
\text { made my choice of service } \\
\text { through their displayed } \\
\text { product lines }\end{array}$ & 161 & 86 & 20 & 17 & 11 & 295 \\
\hline 3 & $\begin{array}{l}\text { Facebook messages about } \\
\text { Nike Lake Resort targets } \\
\text { specific customer (personal } \\
\text { messages) }\end{array}$ & 155 & 89 & 23 & 18 & 10 & 295 \\
\hline 4 & $\begin{array}{l}\text { You gave the management } \\
\text { of Nike Lake Resort } \\
\text { feedback on how they can } \\
\text { improve their services using } \\
\text { Facebook }\end{array}$ & 150 & 102 & 21 & 14 & 08 & 295 \\
\hline 5 & $\begin{array}{l}\text { You purchased Nike Lake } \\
\text { services through their } \\
\text { suasive Facebook messages }\end{array}$ & 154 & 90 & 25 & 17 & 09 & 295 \\
\hline 6 & $\begin{array}{l}\text { You complained about } \\
\text { services dissatisfaction via } \\
\text { Facebook }\end{array}$ & 144 & 102 & 22 & 15 & 12 & 295 \\
\hline TOTAL & $\mathbf{9 2 2}$ & $\mathbf{5 6 1}$ & $\mathbf{1 2 6}$ & $\mathbf{1 0 1}$ & $\mathbf{6 0}$ & $\mathbf{1 7 7 0}$ \\
\hline
\end{tabular}

Source: fieldwork, 2020

In table 4, based on responses 922 indicated strongly agree, 561 indicated agree, 126 indicated neutrality, 101 indicated disagree, while 60 indicated strongly disagree. This implies that Twitter messages have a significant and positive relationship with consumer brand awareness and patronage of Nike Lake Resort services. 


\section{Hypothesis Two}

H2: There is a significant relationship between Facebook messages and consumer brand awareness and patronage of Nike Lake Resort services.

Table 5. Descriptive Statistics

\begin{tabular}{|l|r|r|r|}
\hline & \multicolumn{1}{|c|}{ Mean } & \multicolumn{1}{c|}{$\begin{array}{c}\text { Std. } \\
\text { Deviation }\end{array}$} & \multicolumn{1}{|c|}{ N } \\
\hline Brand & 4.3887 & 1.04767 & 885 \\
Awareness & & & \\
Facebook & 4.2407 & 1.05276 & 885 \\
\hline
\end{tabular}

Table 6. Correlations

\begin{tabular}{|ll|r|r|}
\hline & \multicolumn{1}{|c|}{$\begin{array}{c}\text { Brand } \\
\text { Awareness }\end{array}$} & Facebook \\
\hline Brand & Pearson & 1 & $\mathbf{0 . 9 4 3}^{* *}$ \\
Awareness & Correlation & & 0.000 \\
& Sig. (2-tailed) & 885 & 885 \\
& N & $0.943^{* *}$ & 1 \\
& Pearson & 0.000 & \\
& Correlation & 885 & 885 \\
& Sig. (2-tailed) & \\
& N & \\
\end{tabular}

**. Correlation is significant at the 0.01 level (2-tailed).

Table 5 shows descriptive statistics of the relationship between Facebook messages and consumer brand awareness and patronage of Nike Lake Resort services. The mean value of Facebook messages is 4.2407; while the standard deviation is 1.05276. Also, the mean value of consumer brand awareness and patronage of Nike Lake Resort services is 4.3887; while the standard deviation is 1.04767. By careful observation of standard deviation value, it can be said that there is about the same variability of data points amongst dependent and independent variables. This implies that Facebook messages have a significant and positive relationship with consumer brand awareness and patronage of Nike Lake Resort services.

Also, Table 6 shows the Pearson correlation coefficient for Facebook messages and consumer brand awareness and patronage of Nike Lake Resort services. The correlation shows 0.943 This value is an indication that the correlation coefficient is significant at 0.05 level ( 2 tailed) and implies that there is a significant and positive relationship between Facebook messages and consumer brand awareness and patronage of Nike Lake Resort services $(r=0.943)$. The computed correlation coefficient is greater than the table value of $r=0.195$ with 228 degree of freedom (df $n-2)$ at alpha level for a two-tailed test $(r=0.943, p<0.05)$. 


\section{DISCUSSION OF FINDINGS}

It was revealed that there is a significant positive relationship between Twitter messages and consumer brand awareness and patronage of Nike Lake Resort services ( $r=0.937, p<0.05)$. This finding is in line with the finding by Alhaddad (2015). According to his findings, it was revealed that social media (Twitter messages) is capable of exposing a brand through interpersonal communication and so bolsters the brand image. This is also in agreement with the study conducted by Bayne and Cianfrone (2013). It was revealed in their study that Twitter messages are effective and efficient in creating brand awareness and patronage. In another related study, Karman (2015) revealed that Twitter messages have the capability of increasing brand awareness. Another research revealed that there is a significant positive effect of trust in Twitter on its American and Ukrainian users' patronage intentions (Pentina et al., 2013). When hospitality companies establish their presence online via Twitter, those who have Twitter accounts would access relevant information about their products and services and would go ahead to purchase them if these offerings captivate them. Thus, through Twitter, services awareness can comfortably be created by Nike Lake Resort in Enugu.

Also, it was revealed that there is a significant positive relationship between Facebook messages and consumer brand awareness and patronage of Nike Lake Resort ( $r=0.943$, $p<$ 0.05). In the same vein, Facebook messages were revealed to possess the power of communicating the benefits of a brand to the consumers (Alhadda, 2015). Seo and Park (2018) also revealed a similar relationship between Facebook messages and brand awareness. Tritama and Tarigan (2016) in their study revealed also that Facebook has a significant relationship with brand awareness creation. Similarly, it was revealed in a study conducted to investigate the impact of social media including Twitter and Facebook on consumer patronage of retail stores in Kenya that both social media had a significant positive impact on consumer patronage (Mobango \& Wagandu, 2017). What this relationship shows is that when Nike Lake Resort communicates its services via Facebook, customers will connect with them, view their offerings and if it is attractive to them, they would choose to lodge in the resort and patronize other services they offer.

\section{CONCLUSION}

Social media (Twitter messages and Facebook messages) is in truism a paradigm shift in interpersonal communication. Because everyone is a publisher, companies can design and customize messages to suit different customers. The effect of this media of communication cannot be overemphasized. Social media is interactive, has the speed of message delivery, is cost-effective, has a wider reach and target audience oriented (Okolo et al., 2018). One of the most important aspects of social media is the surety word-of-mouth referral or third-party endorsement of a company's products and services. In this study, consumer brand awareness has a significant relationship with Twitter messages and Facebook messages respectively. It indicates that both Twitter messages and Facebook messages as social media platforms have the capability of influencing the awareness of Nike Lake Resort services. Other related studies have given similar submissions to these influences (Okolo et al., 2018; Chukwu \& Ifediora, 2014; Ogbuji \& Ogbubula, 2018; Akpan et al., 2015; Alam \& Khan, 2015). Through the Twitter messages and Facebook messages channels, the consumers could contribute their 
quota by providing vital information and research data that would help the marketers satisfy their needs in the future. Therefore, the management of Nike lake needs to create Twitter and Facebook accounts to improve on their services by interacting with their clientele better and also serve them better.

\section{REFERENCES}

Abzari, M., Ghassemi, R.A., \& Vosta, L.N. (2014). Analyzing the effect of social media on brand attitude and purchase intention: The case of Iran Khodro Company. Procedia Social and Behavioral Sciences, 143, 822-826.

Ahmad, A., Ahmad, N., \& Nadeem, M. (2014). The study of brand credibility and brand awareness as positive predictors for brand loyalty. Arabian Journal of Business and Management Review (Nigerian Chapter), 2(12), 22-28.

Akpan, C.S., Nwankpa, N.N., \& Agu, V.O. (2015). Influence of Facebook advertisement on the buying behaviour of students of a Nigerian university. International Journal of Humanities and Social Science, 5(7), 135-148.

Alam, M.S., \& Khan, B.M. (2015). Impact of social media on brand equity: A literature analysis. AIMA Journal of Management \& Research, 9(4/4), 1-12.

Alhabash, S., \& Ma, M. (2017). A tale of four platforms: motivations and uses of Facebook, Twitter messages, Instagram, and Snapchat among college students? Reprint, Social Media + Society: Sage.

Alhaddad, A.A. (2015). The effect of advertising awareness on brand equity in social media. International Journal of e-Education, e-Business, e-Management and e-Learning, 5 (2), 73-84.

Ali, Z., Shabbir, M.A., Rauf, M., \& Hussain, A. (2016). To assess the impact of social media marketing on consumer perception. International Journal of Academic Research in Accounting, Finance and Management Sciences, 6(3), 69-77.

Alsanie, S.I. (2015). Social media (Facebook, Twitter messages, WhatsApp) used, and its relationship with the university students contact with their families in Saudi Arabia. Universal Journal of Psychology, 3 (3), 69-72.

Altinay, M., Gucer, E., \& Bag, C. (2017). Consumer behaviour in the process of purchasing tourism products in social media. Journal of Business Research-Turk, 9(1), 381-402.

Anh, P.T., \& Tuan, V.Q. (2016). Determinants of social media influence on consumer's purchasing intentions: The case of Facebook in Vietnam. International Journal of Economics, Commerce and Management, 5(7), 432-442.

Anusha, G. (2016). Effectiveness of online advertising. International Journal of Research Granthaalayah 4 (3), 14-21.

AppeL, G., Grewal, L., Hadi, R., \& Stephen, A.T. (2020). The future of social media in marketing. Journal of the Academy of Marketing Science, 48, 79-95.

Asif, M., Abbas, K., Kashif, M., Hussain, S., \& Hussain, I. (2015). Impact of brand awareness and loyalty on brand equity. Journal of Marketing and Consumer: An International Peer-reviewed Journal, 12, 67-72.

Aslay, C., Lu, W., Bonchi, F., Goyal, A., \& Lakshmanan, L.V.S. (n.d). Viral marketing meets social advertising: Ad allocation with minimum regret. http//www.vldb.org.

Atefeh, F., \& Khreich, W. (2013). A survey of techniques for event detection in Twitter messages. An International Journal: Computational Intelligence, 0(0), 1-33. 
Bayne, K.S., \& Cianfrone, B.A. (2013). The effectiveness of social media marketing: The impact of Facebook status updates on a campus recreation event. Recreational Sports Journal, 37, 147-159.

Belch, G.E., \& Belch, M.A. (2003). Advertising and promotion: An integrated marketing communications perspective. (6th ed.). The McGraw-Hill Companies.

Bertsch, G., \& Ostermann, H. (2011). The effect of wellness brand awareness on expected and perceived service quality. Tourismos: An International Multidisciplinary Journal of Tourism, 6(2), 103-120.

Bilgin, Y. (2018). The effect of social media marketing activities on brand awareness, brand image and brand loyalty. Business \& Management Studies: An International Journal 6 (1), 128-148.

Caers, R., De Feter, T., De Couck, M., Stough, T., Vigna, C., \& Du Bois, C. (2013). Facebook: A literature review. New Media \& Society, 15(6), 982-1002.

Can, L., \& Kaya, N. (2016). Social networking sites addiction and the effect of attitude towards social network advertising. Procedia - Social and Behavioral Sciences, 235, 484-492.

Chukwu, B.I., \& Ifediora, C. U. (2014). Impact of social media networks on consumer patronage in Nigeria: A Study of Jumia and Konga Nigeria Limited. European Journal of Business and Management, 6(30), 63-70.

Cizmeci, F., \& Ercan, T. (2015). The effect of digital marketing communication tools in the creation of brand awareness by housing companies. MEGARON, 10(2), 149-161.

Dhanushanthini, A. (2017). The role of social media marketing in building brand equity- A special reference to the travel \& tourism industry in Sri Lanka. Global Journal of Management and Business Research: E-Marketing, 17(3), 31-37.

Domizi, D. P. (2013). Microblogging to foster connections and community in a weekly graduate seminar course. TechTrends, 57(1), 43-51.

Ekberg, C. (2010). Building a strong brand with marketing communications at the cognitive, affective, and behavioural level - Case Sodertorn University (MBA thesis).

https://www.diva-portal.org.

Ekwueme, A.C., \& Okoro, N. (2018). Analysis of the use of social media advertising among selected online businesses in Nigeria. International Journal of International Relations, Media and Mass Communication Studies, 4(2), 28-43.

Fiegerman, S. (2016). How Twitter messages could still blow it and fade away into social network oblivion. Mashable. http://mashable.com.

Gangadharbatla, H. (2008). Facebook me: Collective self-esteem, need to belong, and internet self-efficacy as predictors of the generation's attitudes toward social networking sites. Journal of Interactive Advertising, 8(2), 1-28.

Groza, M.P., \& Domalgaski, S. (2017). Social media engagement mitigates ad decay effects for super bowl advertisements. The Marketing Management Journal, 27(2), 103-115.

Haida, A., \& Rahim, H.L. (2015). Social media advertising value: a study on consumer's perception. International Academic Research Journal of Business and Technology, $1(1), 1-8$.

Ho, C. (2013). Consumer behaviour on Facebook: Does consumer participation bring positive consumer evaluation of the brand? EuroMed Journal of Business, 9(3), 253-267.

Homburg, C., Klarman, M., \& Schmitt, J. (2010). Brand awareness in business markets: When is it related to firm performance? Intern. J. of Research in Marketing, 27, 201212. 
Ioanas, E., \& Stoica, I. (2014). Social media and its impact on consumer behaviour. International Journal of Economic Practices and Theories, 4(2), 295-303.

Ishola, A., Hamza, S.M., \& Hassam, Z. (2017). Effect of Facebook in influencing student intentions to enrol foreign degree programme in Malaysia. International Journal of Education, Learning and Training, 2(1), 42-57.

Java, A., Finin, T., Song, X., \& Tseng, B. (n.d). Why we Twitter messages: Understanding microblogging usage and communities. http://en.wikipedia.org.

Karman, M.A. (2015). The impact of social media marketing on brand equity toward the purchase intention of Starbucks Indonesia. iBuss Management, 3(2), 77-88.

Kwak, H., Lee, C., Park, H., \& Moon, S. (2010). What are Twitter messages, a social network or news media? http//an.kaist.ac.

Kotler, P., \& Armstrong G. (2012). Principles of Marketing. (14th ed.). Prentice Hall Inc.

Leeflag, P.S.H., Verhoef, P.C., Dahlstrom, P., \& Freundt, T, (2014). Challenges and solutions for marketing in a digital era. European Management Journal, 32, 1-12.

Liu, Y., \& Lopez, R.A. (2016). The impact of social media conversations on consumer brand choices. Mark Lett, 27, 1-13.

Macdonald, E.K., \& Sharp, B.M. (2000). Brand awareness effects on consumer decision making for a common, repeat purchase product: a replication. Journal of Business Research, 48, 5-15.

Mirillo, E., Mureno, M., \& Nunez, A. (2016). The advertising value of Twitter messages Ads: A study among Mexican Millennials. Review of Business Management, 18(61), 436-456.

Mobango, G.E., \& Wagandu, F.R. (2017). Impact of social media on customer patronage of retail stores in Kenya. International Journal of Business Management, 4(2), 6-14.

Nwosu, I.E., \& Anayo, D.N. (2006). Triple-p advertising: principles, processes, practices, Afri-TowersLtd.

Nyekwere, E.O. (2012). An assessment of the use of social media as advertising vehicles: a study of Facebook and Twitter messages (Master's thesis). https://www.academia.edu.

Nyekwere, E.O., Kur, J.T., \& Nyekwere, O. (2013). Awareness and use of social media in advertising: The case of Facebook among residents of Port Harcourt, Nigeria. African Research Review: An International Multidisciplinary Journal Ethiopia, 7(4), 174-194.

Ogbuji, C. N., \& Ogbubula, P. (2018). Social media advertising and electorates' patronage of political parties in Nigeria. Journal of Arts, Science \& Commerce 9(1), 111-119.

Ohajionu, U.C., \& Mathews, S. (2015). Advertising on social media and benefits to brands. Journal of Social Science and Humanities, 10(2), 335-351.

Okolo, V.O., Okafor, J. N., Obikeze, C. O., \& Nduka, C. (2018). Influence of online advertising on consumer brand awareness and patronage of financial institutions in Enugu: A study of united bank for Africa (UBA). Global Scientific Journals 6(8), 452481.

Okolo, V.O., Obikeze, C.O., Ugonna, I.A., \& Nebo, G.N. (2017). Implications of adopting the tenets of public relations as a marketing communications strategy towards discouraging tax evasion among taxpayers in South-Eastern Nigeria. European Journal of Social Sciences 55(2), 61-71.

Okolo, V.O.,Obikeze, C.O., Okonkwo, R.V., Okolo J.U., \& Enyi, F. (2017). Social media as a marketing communications strategy and its impact on the marketing of consumer products in Lagos, Nigeria. International Journal of Research in Finance and Marketing, 7(10), 20-39. 
Okonkwo, E.E., Eyisi, A., \& Ololo, N.G. (2015). Social media platforms and their contributions to tourism development and promotion in Nigeria. Nsukka Journal of the Humanities, 23(2), 103-116.

O'Reilly, N., Berger, I.E., Hernandez, T., Parent, M.M., \& Seguin, B. (2012). Understanding Adolescent sport participation through online social media. Sport, Business and Management: An International Journal, 2(1), 69-81.

Otugo, N.E., Uzuegbunam, C.E., \& Obikeze, C.O. (2015). Social media advertising/marketing: A study of awareness, attitude and responsiveness by Nigerian youths. In Proceeding of the International Conference on Communication, Media, Technology and Design, Dubai, United Arab Emirates, 15-18 May 2015.

Pentina, I., Zhang, L., \& Basmanova, O. (2013). Antecedents and consequences of trust in a social media brand: A cross-cultural study of Twitter. Computers in Human Behavior, 29, 1546-1555.

Rehman, F., Ilyas, M., Nawaz, T., \& Hyder, S. (2014). How Facebook advertising affects buying behaviour of young consumers: The moderating role of gender. Academic Research International, 5(4), 395-404.

Rogers, E.M. (2003). Diffusion of Innovations. (5th ed.). Free Press.

Rouse, M., \& Dean, A. (2014). Facebook. https://whatis.techtarget.com (November 14, 2018)

Sadeghi, T., Khani, M.H., \& Hosseini, S.A. (2013). The investigation of Lavidge and Steiner model's capability in measuring the advertising effectiveness of fire insurance (case study: Insurance company in Mashhad). European Online Journal of Natural and Social Sciences, 2(3), 1559-1567.

Sadhasivam, P., \& Priya, A.N. (2015). A literature review on the impact of television advertising vs. online advertisement among consumers. International Journal of Advanced Research in Computer Science and Management Studies, 3(10), 151-154.

Sahin, I. (2006). Detailed review of Rogers' diffusion of innovations theory and educational technology-related studies based on Roger's. The Turkish Online Journal of Educational Technology 5(2), 1-10.

Seo, E., \& Park, J. (2018). A study on the effects of social media marketing activities on brand equity and customer response in the airline industry. Journal of Air Transport Management, 66, 36-41.

Tapera, J. (2014). The importance of strategic management to business organizations. Research Journal of Social Science and Management, 3(11), 122-131.

Tritama, H.B., \& Tarigan, R.E. (2016). The effect of social media on the brand awareness of a product of a company. CommIT (Communication \& Information Technology) Journal, $10(1), 9-14$.

Wikipedia (2018). Online advertising. Available: from https://en.wikipedia.org (December $03,2018)$.

Wikipedia (2018). Facebook. https://en.wikipedia.org (December 03, 2018).

Williams, S.A., Terras, M., \& Warwick, C. (2013). What people study when they study Twitter messages: Classifying Twitter messages related to academic papers. Journal of Documentation, 69(3), 1-74.

Woodcock, N., \& Stone, M. (2012). Simple strategies to win and keep customers profi tably. Journal of Database Marketing \& Customer Strategy Management, 19(4), 275-285. 
Yildiz, S., Yildiz, E., \& Tehci, A. (2016). May. Influence of Facebook applications on consumer purchase intention: A case study of generation y. In a Proceedings of the 6th International Interdisciplinary Business-Economics Advancement Conference Miami, Florida, USA, 9-13 May 2016.

Zubiaga, A., Spina, D., Martinez, R., \& Fresno, V. (2013). Real-time classification of Twitter messages trends. Journal of the American Society for Information Science and Technology, http://support.Twitter messages.com. 